fill the obligations they have assumed. Reports were received from twenty-seven holders of grants and accepted as reports of progress. It was voted to make the following new grants :

No. $170, \$ 100$ to Professor Arthur L. Foley, Indiana University, Bloomington, Indiana, for photographic researches on the spectra of various gases, the money to be applied to the purchase of quartz tubes. (Application 1,243.)

No. 171, $\$ 250$ to Professor Paul Schiefferdecker, Bonn, Germany, for the investigation of the microscopic structure of muscles. (Application 1,252.)

No. $172, \$ 75$ to K. Stolyhwo, rue Kaliksta, Varsovie, Poland, for the archeological exploration of the Cave of Lary, Poland. (Application 1,264.)

No. $173, \$ 180$ to Professor H. Konen, Fürstenbergerstrasse 4, Münster, W., Germany, for the study of the lower end of the spectrum, the money to be used for the purchase of quartz rock salt objectives. (Application 1,245.)

No. $174, \$ 100$ to Dr. Paul D. Lamson, Bahnhofstrasse 20, Würzburg, Germany, for researches on the pharmacotherapy of snake-bites. (Application 1,258.)

No. 175, $\$ 40$ to W. Doberck, Esq., Kowloon, Elgin Road, Sutton, Surrey, England, for observations on comets, the money to be used for the purchase of a comet eyepiece. (For application, see Grants made, Report 383.)

No. 176, $\$ 250$ to Professor Th. Boveri, Zoologisches Institut, Würzburg, Germany, for experiments on the rôle of the separate elements of cells in heredity. (Application 1,249.)

Charles S. Minot, Secretary

Harvard Medical School, BOSTON

\section{JOHN BERNHARDT SMITH}

THE many personal friends of Doctor John Bernhardt Smith, state entomologist of New Jersey, had known for many months that he was in a most serious condition of health, but were none the less shocked and grieved to learn of his death on March 12 last.

Few men have contributed more to the advancement of the study of entomology in the United States, through both the systematic and economic sides, than has the late New Jersey entomologist. He was born in New York City on November 21, 1858, and was educated in the schools of New York City and Brooklyn. He was admitted to the bar in $\mathbf{1 8 8 0}$ and practised law in Brooklyn between 1880 and 1884. As a young man, he was greatly interested in the study of insects and joined the Brooklyn Entomological Society, devoting himself at first to the study of Coleoptera and afterwards turning his attention to Lepidoptera. He became the editor of the Bulletin of the Brooklyn Entomological Society which afterwards developed into the journal known as Entomologica Americana, the most prominent periodical of its kind in those days for the publication of short papers and notes.

Up to 1884, Doctor Smith was known only as a systematic entomologist, but in that year he was brought by the late C. V. Riley to Washington and became field agent of the Bureau of Entomology, U. S. Department of Agriculture, and spent two years in investigating insects affecting the hop and the cranberry. In 1886, he was transferred to the U. S. National Museum, where he remained as assistant curator of insects until 1890.

Juring this period, he was active in his systematic work publishing a number of excellent papers, and became prominent in the scientific life of Washington, joining the Cosmos Club and being made secretary of the Biological Society of Washington.

With the founding of the state agricultural stations under the Hatch Act, he was appointed entomologist of the State Agricultural Experiment Station of New Jersey and there really began his important economic work, which lasted until his fatal illness came. All the difficulties of insect emergency which the agricultural and horticultural interests of New Jersey had to face during that period were met by Doctor Smith with a rare comprehension and an equally rare ability to handle them. He was foremost in the work against the San Jose scale in the early days and took an equal rank in the warfare against all the other threatening foes to agriculture and, in the last few years, conducted an admirably 
planned and successful crusade against the traditional insect of New Jersey, the mosquito. His mosquito work was based upon original observations which introduced revolutionary ideas into culicidology and his work on the salt marsh mosquitoes which fly inland from their breeding-places for many miles came as a startling revelation to the "old fogy" students of mosquitoes, of whom the writer of this notice was one. Further than that, Doctor Smith so impressed his views upon the legislature and the governor of his state that his mosquito work was supported by large appropriations.

Through all this period of economic work, Smith was constantly working upon other aspects of entomology. Every few months would appear a systematic paper upon that difficult and complex group, the family Noctuidæ, and in the course of his New Jersey career he published two enormous catalogues of the insects of New Jersey.

He was also the author of two admirable books, "Economic Entomology for the Farmer and Fruit Grower," Lippincott, 1896, and "Our Insect Friends and Foes," Lippincott, 1909. In addition to the position of entomologist of the New Jersey State Agricultural Experiment Station, he was professor of entomology in Rutgers College and state entomologist of New Jersey. He was president of the Association of Economic Entomologists in 1896 and president of the Entomological Society of America in 1910. In 1891 he was given the honorary degree of Sc.D. by Rutgers College.

While not a pioneer in entomology in the United States, Smith was a leader in the second generation of men who have helped to make American economic entomology assume the first rank in the world. I. O. How ARD

\section{SCIENTIFIC NOTES AND NEWS}

Professor Abbott Lawrence Rotch has bequeathed to Harvard University the Blue Hill Meteorological Observatory, which he established in 1885 and had directed up to the time of his death. He has further provided an endowment fund of $\$ 50,000$.
THE will of Lord Lister disposes of property valued at $£ 66,166$. In addition to a number of family bequests he left $£ 10,000$ each to the Royal Society, King Edward's Hospital Fund, King's College Hospital and the North London and University College Hospital. $\mathrm{He}$ stated that he did not wish that his name should be "in any way associated with these sums in the future." He also left $£ 20,000$ to the Lister Institute of Preventive Medicine, and requested his nephews, Mr. Rickman John Godlee and Mr. Arthur Hugh Lister, to arrange his scientific manuscripts and sketches, destroying or disposing of such as were of no permanent scientific interest. $\mathrm{He}$ left his manuscripts and sketches when so arranged to the Royal College of Surgeons, England. In the bequest of his Orders and medals to the Edinburgh University, Lord Lister stated: "I expressly declare that it is my intention that the university authorities for the time being shall be perfectly at liberty to dispose of all or any part of the gift-for example, by having the medals melted down or the diplomas or other writings destroyedat any time and in any manner that may seem to them desirable."

Dr. IRA Remsen has tendered his resignation as president of the Johns Hopkins University. He will remain professor of chemistry, which he has been since the opening of the university in 1876. Dr. Remsen's letter of resignation in part reads as follows: "For some time past it has seemed best to me that I should retire from the presidency of the university, but those whom I have consulted have urged me to postpone action until certain important things have been accomplished. This has now been done and I accordingly tender my resignation to take effect at the end of the present academic year. I have held the position for eleven years. This covers a fairly well-defined period in the history of the university, a period of steady growth and especially of preparation for a new era, which while maintaining and strengthening the old ideals and high standards of the university, will lead to larger and in some directions new 